Published by LPMP Imperium

Journal homepage: https:/ / ejournal.imperiuminstitute.org/ index.php/ BERDAYA

\title{
Sosialisasi Penerapan Pajak Penghasilan Final Untuk Usaha Mikro Kecil Menengah
}

\author{
M uti'ah ${ }^{1 *}$, Ratna Mappanyukki ${ }^{2}$ \\ 1-2Fakultas Ekonomi dan Bisnis, Universitas Mercu Buana \\ *Email: mutiah@mercubuana.ac.id
}

\section{ABSTRACT}

This Community Service Program (PKM) aims to improve knowledge and skills in making simple bookkeeping and calculation of profit/loss as a basis for calculating taxes on Micro, Small and Medium Enteprises (MSMEs) in Meruya Jakarta. This activity has a very mutual relationship with the MSME's communities. The method used in this activity is the scheduled training method. The results of training conducted to MSME actors have implications: (1). It is recommended that every MSME performer keep his or her bookkeeping business properly and correctly as a basis for calculating taxes; (2). Local governments, through the Office of Cooperatives and MSME (Dinas Koperasi dan UMKM) can contribute to providing guidance and training for MSMEs actors, because the results of the business they get contribute to the Regional Budget.

Keywords: MSMEs, income tax

\section{BERDAYA}

67

\section{Article History}

Received 12 Oct 2019

Revised 2 Nov 2019

Accepted $25 \mathrm{~N}$ ov 2019

First Published: 04 Dec 2019

\section{Reviewing Editor}

Hendryadi, STEI Indonesia

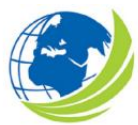

BERDAYA, Vol 1, No.2, December 2019, pp. 66-74 eISSN XXXX-XXXX

To cite this article: Muti'ah, M., \& Mappanyukki, R. (2019). Sosialisasi Penerapan Pajak Penghasilan Final Untuk Usaha Mikro Kecil Menengah. BERDAYA: Jurnal Pendidikan dan Pengabdian Kepada M asyarakat, 1(2), 67-74

(c) $\bigodot_{\mathrm{BY}}$ 


\title{
Sosialisasi Penerapan Pajak Penghasilan Final Untuk Usaha Mikro Kecil Menengah
}

\author{
M uti'ah ${ }^{1 *}$, Ratna Mappanyukki 2 \\ 1-2Fakultas Ekonomi dan Bisnis, Universitas Mercu Buana \\ JI. Meruya Selatan No.1, RT.4/ RW.1, Meruya Sel., Kec. Kembangan, Kota Jakarta \\ Barat, Daerah Khusus I bukota Jakarta 11650 \\ *Email: mutiah@mercubuana.ac.id
}

\begin{abstract}
ABSTRAK
Program Pengabdian Masyarakat ini bertujuan untuk meningkatkan pengetahuan dan keterampilan membuat pembukuan sederhana serta perhitungan laba/ rugi sebagai dasar untuk menghitung pajak pada UMKM di kelurahan Meruya Selatan. Khalayak sasaran strategis dalam kegiatan ini adalah pelaku UMKM yang ada di kelurahan Meruya Selatan. Kegiatan ini memiliki keterkaitan yang sangat mutualis dengan pihak Dinas Koperasi dan UMKM Jakarta Barat. Metode yang digunakan dalam kegiatan ini adalah metode pelatihan secara terjadwal. Hasil pelatihan yang dilakukan pada pelaku UMKM memberikan implikasi: (1). Sebaiknya setiap pelaku UMKM untuk menjaga kelangsungan usahanya melakukan pembukuan dan baik dan benar sebagai dasar untuk menghitung pajak; (2). Pemerintah daerah, melalui Dinas Koperasi dan UMKM dapat berkontribusi untuk memberikan pembinaan dan pelatihan bagi para pelaku UMKM, karena hasil usaha yang mereka dapatkan turut menyumbang Anggaran Pendapatan dan Belanja Daerah.
\end{abstract}

Kata Kunci : pajak penghasilan, UMKM

\section{PENDAHULUAN}

Indonesia merupakan salah satu Negara yang menjadikan pajak sebagai tulang punggung penerimaan Negara. Penerimaan Negara yang berasal dari sektor perpajakan memiliki porsi terbesar dalam struktur Anggaran Pendapatan dan Belanja Negara (APBN). Pajak menjadi sumber pembiayaan pembangunan menggantikan dominasi penerimaan Negara dari penjualan minyak dan gas bumi yang menurun seiring dengan rendahnya harga minyak Internasional. Hal ini tertuang dalam Anggaran Penerimaan dan Belanja Negara (APBN) yang menyatakan bahwa sumber pendapatan terbesar didapat dari sektor perpajakan. Proporsi penerimaan Negara dari pajak terus meningkat setiap tahunnya, bahkan mencapai angka $80 \%$ pada tahun 2015.

Dari tahun ke tahun kegiatan pemerintah dalam pembangunan nasional semakin meningkat, hal ini berpengaruh pada kebutuhan akan Anggaran Belanja N egara, bahwa target jumlah penerimaan pajak setiap tahunnya meningkat mengikuti undang-undang anggaran pendapatan dan belanja Negara untuk tahun tersebut. Semakin meningkat jumlah anggaran belanja N egara maka membutuhkan sumber penerimaan yang semakin besar pula.

Tuntutan akan peningkatan penerimaan Negara dari sektor pajak, untuk menghadapi potensi resiko global tahun 2017, pemerintah merespon kebijakan fiscal yang dianggap kredibel, efektif dan efisien. Target penerimaan pajak mencapai 85,6\% dari total pendapatan Negara, oleh karena itu maka pemerintah melalui Direktorat Jenderal Pajak melakukan berbagai rencana dan 
langkah-langkah strategis dari waktu kewaktu berupa berbaikan dan penyempurnaan regulasi dan system administrasi atau disebut reformasi perpajakan.

Dalam pembangunan nasional, Usaha Mikro Kecil dan Menengah (UMKM) mempunyai peranan yang sangat strategis, dimana UMKM di berbagai Negara termasuk Indonesia merupakan salah satu penggerak perekonomian rakyat, dimana kebanyakan para pengusaha UMKM berangkat dari industry keluarga atau rumahan. UMKM lebih banyak bersifat padat karya dari pada padat modal, artinya UMKM membutuhkan sekaligus menyediakan lapangan kerja bagi banyak orang, oleh karena itu UMKM mempunyai peran besar mengingat Indonesia masih dibelit persoalan pengangguran yang cukup tinggi.

Pembangunan UMKM merupakan rangka mereduksi pengangguran dan menyerap angkatan kerja. Jumlah UMKM dan penyerapan tenaga kerja di Indonesia dari tahun 2013 sampai dengan 2017 dapat kita lihat pada tabel berikut ini :

Tabel 1. Pertumbuhan Jumlah UM KM

\begin{tabular}{|l|l|l|}
\hline Tahun & Jumlah UMKM & Tenaga Kerja \\
\hline 2013 & 56.539 .560 & 107.657 .509 \\
\hline 2014 & 57.900 .787 & 114.144 .082 \\
\hline 2015 & 59.267 .759 & 123.229 .386 \\
\hline 2016 & 61.656 .547 & 112.828 .610 \\
\hline 2017 & 62.928 .077 & 116.673 .416 \\
\hline
\end{tabular}

Sumber : www.depkop.go.id

Tabel 1. menunjukkan pertumbuhan UMKM dan penyerapan tenaga kerja dari tahun ke tahun meningkat signifikan. UMKM sebagai salah satu pilar kekuatan perekonomian, hal ini disebabkan karena UMKM mempunyai fleksibilitas dan kemampuan menyesuaikan diri terhadap kondisi pasar yang berubah dengan cepat dibanding dengan perusahaan skala besar. UMKM lebih tangguh dalam menghadapi krisis ekonomi, kinerja UMKM beberapa tahun terakhir menunjukkan peningkatan. Perkembangan sektor UMKM yang demikian menyiratkan bahwa terdapat potensi yang besar, jika dikelola dan dikembangkan dengan baik.

UMKM memiliki keunggulan diantaranya mampu mengangkat perekonomian rakyat, dengan menciptakan lapangan kerja, mampu menyerap tenaga kerja dan penggerak peningkatan ekspor non migas, sehingga dapat meningkatkan pendapatan masyarakat. Sementara itu disisi lain secara umum, khususnya dalam aspek financial hanya sedikit UMKM yang mengalami perkembangan dalam hal kinerja keuangannya.

Pengelolaan Keuangan menjadi salah satu aspek penting bagi kemajuan perusahaan. Pengelolaan keuangan dapat dilakukan melalui akuntansi. Akuntansi merupakan proses sistematis untuk menghasilkan informasi keuangan yang dapat digunakan untuk pengambilan keputusan bagi penggunanya. Karena dari laporan keuangan dapat diketahui apakah perusahaan dalam kondisi sehat atau merugi. Namun tentu saja proses harus mengacu pada prinsip-prinsip dan kaidah akuntansi yang berlaku umum. Acuan utama yang umumnya digunakan dalam penyusunan dan penyajian laporan keuangan di Indonesia adalah pernyataan Standar Akuntansi Keuangan (PSAK) yang disusun oleh Dewan Standar Akuntansi Keuangan Ikatan A kuntansi Indonesia (IAI).

Adapun manfaat dari akuntansi antara lain : 1). UMKM dapat mengetahui kinerja keuangannya. 2). UMKM dapat mengetahui, memilah, dan membedakan harta usaha dengan harta pribadi. 3). UMKM dapat mengetahui posisi dana, baik sumber maupun penggunaannya. 
4). UMKM dapat menghitung pajak sesuai Perundang-undangan Perpajakan.

Penyajian laporan keuangan perusahaan merupakan kegiatan yang harus dilakukan oleh setiap pelaku usaha sebagaimana diatur dalam pasal 28 ayat (1) Undang-undang Ketentuan Umum dan Tata Cara Perpajakan (KUP). Dalam pasal 28 ayat (1) Undang-undang KUP, menjelaskan bahwa : Wajib Pajak orang pribadi yang melakukan kegiatan usaha atau pekerjaan bebas dan wajib pajak Badan di Indonsia wajib menyelenggarakan pembukuan. Berdasarkan pasal 28 ayat (1) tersebut, laporan keuangan menjadi salah satu komponen mutlak yang harus dilakukan oleh wajib pajak (pelaku usaha), oleh karena itu, mencatat kegiatan usaha yang terjadi dan menyusun laporan keuangan harus ditumbuhkan dikalangan UMKM, karena laporan keuangan sebagai dasar untuk menghitung pajak yang harus dibayar oleh pelaku usaha.

\section{Permasalahan M itra dan Solusi}

Berdasarkan analisis situasi tersebut diatas, maka rumusan masalah pada pengabdian masyarakat ini adalah :

1. UMKM masih banyak belum mampu menyusun pembukuan atau laporan keuangan sesuai perundang-undangan perpajakan .

2. Karena belum mampu menyusun pembukuan atau laporan keuangan, maka UMKM merasa kesulitan dalam menghitung pajak penghasilannya.

3. UMKM selaku wajib pajak memerlukan solusi untuk menyusun penghitungan pajaknya.

Solusi yang ditawarkan dalam kegiatan ini adalah melakukan sosialisasi kepada UMKM di Meruya Selatan, bagaimana menyusun pembukuan atau laporan keuangan fiskal, dan bagaimana menghitung pajak penghasilan final UMKM. Dalam menghitung pajak UMKM tahapan-tahapan yang harus dijalani adalah :

1. Tahap pemahaman Peraturan Perpajakan serta perubahannya, tentang pajak penghasilan final untuk UMKM

2. Tahap pemahaman laporan keuangan fiscal

3. Tahap pemahaman penghitungan pajak penghasilan final UMKM berdasarkan Perundangundangan Perpajakan.

\section{Permasalahan Prioritas Khalayak Sasaran \\ MATERI DAN METODE}

Fungsi akuntansi adalah mengkomunikasikan informasi ekonomi, yaitu realita ekonomi suatu organisasi. Adanya informasi akuntansi membantu dalam menyelenggarakan kegiatan usaha mandiri. Adapun manfaat dari akuntansi adalah dapat mengetahui kinerja keuangannya. laporan keuangan menjadi salah satu komponen mutlak yang harus dilakukan oleh wajib pajak (pelaku usaha), oleh karena itu, mencatat kegiatan usaha yang terjadi dan menyusun laporan keuangan harus ditumbuhkan dikalangan UMKM, Namun pada kenyataannya berdasarkan survey pendahuluan Para pelaku Usaha Kecil dan Menengah memiliki kebiasaan mencatat transaksi secara sederhana dan tidak lengkap. 
Muti'ah, M., \& Mappanyukki, R

Sosialiasi Penerapan Pajak Penghasilan U M KM

\section{Lokasi kegiatan}

Kegiatan dilaksanakan di UMKM Kelurahan Meruya Selatan, Kembangan Jakarta Barat pada Tanggal 11 A pril 2019.

\section{M etode Kegiatan}

Pelaksanaan kegiatan pengabdian pada masyarakat ini dilakukan dengan menggunakan metode OLU yaitu :

1. Orientasi : Pengenalan konsep dan teori oleh pengajar dengan metode pengajaran didepan kelas.

2. Latihan : dalam sesi ini peserta akan diberikan beberapa soal yang relevan dengan topik yang dibahas instruktur. Peserta harus aktif instruktur hanya sebagai fasilitator.

3. Umpan Balik: Setelah peserta mengerjakan latihan yang diberikan, maka instruktur akan membahas dikelas. Peserta dapat melihat kesalahan yang dibuat sehingga akan memberikan pemahaman yang baik tentang konsep yang diajarkan.

\section{Rancangan Evalusi}

Untuk mengukur keberhasilan pengabdian ini akan dilakukan evaluasi setelah satu bulan pelaksanaan pengabdian masyarakat, dilakukan dengan cara wawancara dan diskusi. M etode ini dipilih untuk mengetahui apakah pelaporan keuangan yang dibuat UMKM sudah sesuai perundang-undangan perpajakan setelah mengikuti pelatihan dan sebagai masukan sehingga tujuan dari pelaksanaan program pengabdian masyarakat tercapai.

\section{HASIL DAN PEMBAHASAN}

Sesuai dengan permasalahan yang ada para pengusaha kecil yang baru memulai usaha khususnya di RPTRA Menara, meruya selatan pada umumnya sering mengabaikan pembukuan, dengan anggapan membuat pembukuan adalah hal yang rumit dan memerlukan kemampuan untuk melakukan pembukuan. Pada umumnya para pemilik usaha hanya fokus pada produk dan pemasaran saja tanpa memperhatikan cash-flow keuangan setiap harinya. Sebenarnya fokus pada produk dan pemasaran adalah hal yang wajar bagi pengusaha yang baru memulai usahanya, karena masih dalam proses penetrasi pada target pasar. Biasanya proses penetrasi pasar berlangsung beberapa bulan pertama, hingga produk benar-benar dikenal oleh pelanggan dan meraup omset yang cukup tinggi.

Pelatihan dilakukan untuk memberikan wawasan mengenai tujuan, kegiatan-kegiatan yang akan dilakukan, serta memberikan pemahaman tentang konsep-konsep manajerial sehubungan dengan pengelolaan usaha kaitannya dengan akuntansi. Adapun alur pelatihan membuat pembukuan dan penghitungan pajak UMKM dimulai dari :

\section{Tahap Persiapan ;}

Tahap persiapan, yang terdiri dari tahap : a). Penyiapan bahan administrasi sesuai dengan kebutuhan pelaksanaan latihan, b). Melakukan koordinasi dengan pengurus RPTRA, yang selanjutnya RPTRA koordinasi dengan pelaku UMKM, c). Menyiapkan materi pelatihan, d). Menyiapkan jadual pelatihan selama 1 (satu) hari efektif. 


\section{Tahap Pelaksanaan ;}

Tahap Pelaksanaan, yang terdiri dari : a). Melakukan Pelatihan membuat pembukuan dan menghitung pajak bagi UMKM, b). Simulasi terbatas membuat pembukuan dan menghitung pajak bagi UMKM.

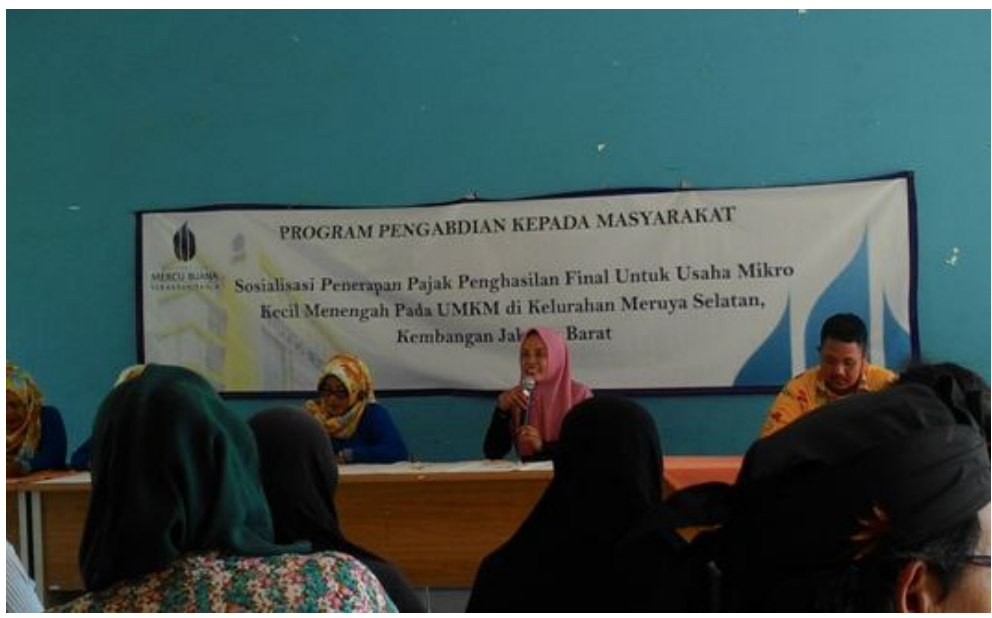

Gambar 1. Pemberian materi oleh Tim Pelaksana Sumber: dokumentasi Tim Pelaksana

\section{Tahap Evaluasi}

Pada pelatihan pembukuan dan menghitung pajak bagi UMKM terlebih dahulu diberikan pemahaman mengenai pentingnya penggunaan pembukuan dalam usaha. Jika dilihat secara teoritis. Pembukuan terdiri dari 3 (tiga) kegiatan dasar yakni : 1). Mengidentifikasi, 2). Mencatat dan 3). Mengkomunikasikan peristiwa ekonomi suatu organisasi kepada pengguna yang tertarik..

1. Identifikasi, Dalam hal identifikasi (identifies) kejadian ekonomi adalah mengajarkan bahwa dalam suatu bisnis, kejadian ekonomi bisa terjadi mulai dari membeli sampai dengan menjual dan menjadi uang kembali.

2. Mencatat, adalah mencatat seluruh bukti-bukti kejadian ekonomi. Dalam hal mencatat buktibukti ini, dijelaskan bahwa semua transaksi harus disertai dengan bukti-bukti yang dapat dipertanggungjawabkan, apabila bukti-bukti belum ada maka harus dibuatkan bukti, selanjutnya diminta agar setiap transaksi harus ada bukti.

3. Mengkomunikasikan peristiwa ekonomi suatu organisasi kepada pengguna yang tertarik, dengan kata lain akuntansi menginformasikan mengenai keuangan sebuah perusahaan yang dapat digunakan untuk melihat bagaimana kinerja perusahaan dalam suatu periode tertentu.

Pelatihan pembukuan lebih kepada hal-hal yang sifatnya teknis pencatatan khususnya yang berkaitan dengan akuntansi. A dapun kegiatan yang dilaksanakan selama pengabdian yaitu :

Bagi perusahaan kecil, umumnya fokus utamanya adalah pada produk, dan pemasarannya, sedang pembukuan merupakan sesuatu yang rumit. Pada dasarnya transaksi terjadi berulang dengan transaksi yang sama, oleh karena itu untuk kemudahan, kesederhanaan pencatatan, dan efisiensi lebih tepat menggunakan jurnal khusus. 
Pada jurnal khusus disediakan kolom-kolom untuk mencatat transaksi yang berulangulang, sehingga pencatatannya cukup dengan menuliskan jumlah (angka) pada kolom yang telah tersedia. Adapaun jurnal khusus yang diperlukan dalam UMKM antara lain :

1. Jurnal Pembelian : digunakan untuk mencatat pembelian secara kredit

2. Jurnal Pengeluaran Kas : digunakan untuk mencatat pengeluaran atau pembayaran secara tunai.

3. Jurnal Penjualan : digunakan untuk mencatat penjualan secara kredit

4. Jurnal Peneri maan Kas : digunakan untuk mencatat penerimaan uang tunai

5. Jurnal U mum : digunakan untuk mencatat retur, penyusutan dII.

Setelah diberikan pelatihan peserta pelatihan di keluarahan Meruya Selatan, mereka memiliki kemampuan membuat pembukuan sederhana yang digunakan untuk mencatat kegiatan usaha. Adapun hasil dari kegiatan pelatiha pembukuan untuk menghitung pajak yang dirasakan para pelaku UMKM di kelurahan Meruya Selatan 1). Sebagian besar para pelaku UMKM yang ada di kelurahan Meruya Selatan belum bisa membuat pembukuan sederhana namun setel ah dilakukan pelatihan mengaku dapat mencatat pembukuan sederhana untuk usahanya.

\section{KESIM PULAN}

Pelatihan pembukuan dan penghitungan pajak bagi pelaku UMKM di kelurahan Meruya Selatan dilakukan pada bulan April 2019 dengan narasumber dari Universitas Mercu Buana. Adapun alur pelatihan membuat pembukuan dan penghitungan pajak bagi pelaku UMKM di kelurahan Meruya Selatan. Berdasarkan pada proses pelatihan yang dilakukan pada pelaku UMKM di kelurahan Meruya Selatan disarankan: (1). Sebaiknya setiap pelaku UMKM untuk menjaga kelangsungan usahanya melakukan pembukuan dan baik dan benar sebagai dasar untuk menghitung pajak; (2). Pemerintah daerah melalui Dinas Koperasi dan UMKM selalu memberikan pembinaan dan pelatihan bagi para pelaku UMKM yang ada di kelurahan Meruya Selatan, karena hasil usaha yang mereka dapatkan turut menyumbang Anggaran Pendapatan dan Belanja Daerah.

\section{REFERENSI}

Suandy, E. (2011). H ukum Pajak. Edisi 5. Jakarta: Salemba Empat.

Hanafi, M. M. dan Halim, A. (2009). A nalisis Laporan Keuangan, Edisi ke-4, Cetakan Pertama, Yogyakarta: UPP STIM YKP

Herry , (2012). A nalisis Laporan Keuangan, Jakarta, PT. Bumi Aksara

Ikatan Akuntansi Indonesia. (2015). Pernyataan Standar A kuntansi Keuangan, Jakarta: Salemba Empat 
This page intention to blank... 